\title{
The Association of the Urobilin "Early Peak" and Erythropoiesis in Man*
}

\author{
Peter V. D. Barrett, $\dagger$ Martin J. Cline, and Nathaniel I. Berlin \\ (From the Metabolism Branch, National Cancer Institute, National Institutes of Health, \\ Bethesda, Md.)
}

In a normal individual the administration of isotopically labeled glycine $(1,2)$ results in two peaks of radioactivity in the excreted fecal bile pigment. The first or "early" labeled peak of fecal bile pigment excretion occurs within the first few days and cannot be explained on the basis of the breakdown of normal circulating red cells. The second peak occurs 100 to 130 days after administration of the isotopic precursor and coincides with the termination of the life-span of the group of red cells that contains the labeled precursor. When the conversion of intravenously administered glycine- $2-{ }^{14} \mathrm{C}$ to serum bilirubin $-{ }^{14} \mathrm{C}$ was studied, two peaks of bilirubin specific activity were found, the first at 24 hours and the second at the third to fourth day (3). It must be recognized that the single observed fecal urobilin early peak is a result of fusion of the two early labeled peaks in the gastrointestinal tract and that the changes measured in these patients could, in theory, be due to a quantitative change in either component.

Several theories have been proposed to explain the first or early fecal peak. The most widely accepted is that this pigment is derived from red cells that are destroyed before or shortly after their release from the bone marrow. For this reason the early peak has been thought of as representing "ineffective" erythropoiesis. With this hypothesis, London, West, Shemin, and Rittenberg (1) and Gray, Neuberger, and Sneath (2) calculated that in a normal individual 11 to $20 \%$ of erythropoiesis is represented in this peak. However, recent studies have been interpreted as showing that the early peak might arise by a direct synthetic pathway from a common precursor pool that does

* Submitted for publication August 9, 1965 ; accepted July $18,1966$.

$\dagger$ Address requests for reprints to Dr. Peter V. D. Barrett, National Cancer Institute, National Institutes of Health, Bethesda, Md. 20014. not require heme as an intermediate and, thus, is not necessarily related to erythropoiesis (4).

James and Abbott (5) reported the presence of an elevated early peak in two patients who eventually developed acute granulocytic leukemia. One of these patients had erythroid hyperplasia of the bone marrow, and the other had erythroid aplasia. From these observations it was concluded that the major portion of the early peak could not be associated with erythropoiesis. However, this conclusion is at variance with studies in which the amount of labeled urobilin in the early peak did increase after an experimental hemorrhage or was found to be increased in disease states associated with increased rates of erythropoiesis (6).

The present study was undertaken in an attempt to define the relationship between erythropoiesis and the early labeled peak of urobilin by studying a given individual at two different rates of red cell production. With the exception of two patients who were studied before and after an experimental hemorrhage $(7,8)$, this has not been done previously. Four patients with hematologic diseases that might respond favorably to therapy were selected for study. Before and after treatment these patients were given glycine- $2-{ }^{14} \mathrm{C}$, and the specific activity of urobilin- ${ }^{14} \mathrm{C}$ was determined. In addition, erythrokinetic function was evaluated by using either ${ }^{59} \mathrm{Fe}$ or glycine-2-14 $\mathrm{C}$ as a precursor of heme. We feel that the results of these studies support the concept that in man most of the early labeled peak is associated with erythropoiesis.

\section{Methods}

Fecal urobilin isolation. For each study the patients were given intravenous injections of $100 \mu \mathrm{c}$ glycine-2- ${ }^{14} \mathrm{C}$ (SA 2.6 to $4.0 \mu \mathrm{c}$ per $\mu$ mole) in a volume of 1 to $5 \mathrm{ml}$ over a 10 -second period. Stool samples were collected daily and stored at $-20^{\circ} \mathrm{C}$ until analysis. Early in the study Watson's original method for the isolation of fecal urobilin was used in a modified form $(7,9)$, but the most 
recent method of Watson and his co-workers (10) was used in later isolations.

The term "urobilin" is used generically in this report to include the closely related pigments urobilin IXa, $d$-urobilin, and $l$-urobilin (stercobilin), which are identical from a physiologic point of view and which all may be isolated with the above method (10). However, in any given individual only one species of urobilin is usually present. Except for patient W.G., the specific optical rotation of the urobilin crystals of each sample was determined in chloroform, ${ }^{1}$ and the values obtained were consistently within the accepted limits of purity for $i$ (inactive)-, $d$-, or $l$-urobilin (11). In addition, the specific activity of urobilin crystals obtained by these methods was found to be constant after crystallization from ethyl acetate. To determine the specific activity of the urobilin crystals, we plated 1 to $2 \mathrm{mg}$ on a preweighed $5-\mathrm{cm}$ planchet with the aid of a turntable and counted in a low background thin window $\beta$-counter ${ }^{2}$ with an efficiency of $22 \%$ and a background of $2 \mathrm{cpm}$. All samples were counted for at least a half-hour or until a minimum of 1,000 counts had been observed.

Hemin isolation. The method of Fischer (12) was used for most of the samples. The crystalline material was plated and counted for ${ }^{14} \mathrm{C}$ content as with urobilin. However, for patients S.S. and J.F., hemoglobin was ex-

1 Standard polarimeter, Hilger and Watts, Ltd., London, England.

2 Sharp Laboratories, Inc., La Jolla, Calif. tracted, and calculations were made to convert the data to the specific activity of hemin (13). The values given for each patient represent maximal specific activities at 10 to 20 days.

Ferrokinetics. Twenty $\mu \mathrm{c}$ of ${ }^{50} \mathrm{Fe}$ in the form of ferrous citrate with a specific activity of 2 to $40 \mathrm{mc}$ per $\mathrm{mg}$ was used in each study. The method of Huff and coworkers (14) was used to determine the plasma radioiron disappearance half-time and the red cell radioiron uptake.

Blood volume. The ${ }^{51}$ chromium method of Sterling and Gray (15), as modified by Read (16), was used.

DFP red cell life-span. Tritiated diisopropylfluorophosphate (DFP- $\left.{ }^{8} \mathrm{H}\right)$ was used as a red cell label as previously described (17).

Isotopic measurements. Samples containing ${ }^{51} \mathrm{Cr}$ and ${ }^{50} \mathrm{Fe}$ were counted in a well-type scintillation counter with a sodium iodide (thallium-activated) crystal and a single channel spectrometer. When both ${ }^{51} \mathrm{Cr}$ and ${ }^{50} \mathrm{Fe}$ were in the same sample, a correction was made for ${ }^{\circ 0} \mathrm{Fe}$ activity in the ${ }^{51} \mathrm{Cr}$ counting window.

Crystalline urobilin $-{ }^{14} \mathrm{C}$ or hemin $-{ }^{14} \mathrm{C}$ was counted by plating the material infinitely thin on a $5-\mathrm{cm}$ diameter planchet and counting in a thin window low background counter. Planchets plated with hemin that contained both ${ }^{50} \mathrm{Fe}$ and ${ }^{14} \mathrm{C}$ were counted twice, with sufficient time between the two countings to allow at least half of the ${ }^{80} \mathrm{Fe}$ to decay. Assuming that the radioactivity due to ${ }^{14} \mathrm{C}$ remained constant during this period, one may then calculate the radioactivity due to ${ }^{14} \mathrm{C}$ alone.

TABLE I

Erythrokinetic data for four patients with varying rates of erythropoiesis and for two hematologically normal patients*

\begin{tabular}{|c|c|c|c|c|c|c|c|c|c|c|c|}
\hline Patient & Study & $\begin{array}{c}\text { Plasma } \\
\text { iron } \\
\text { turn- } \\
\text { over }\end{array}$ & $\begin{array}{l}\text { RBC } \\
\text { iron } \\
\text { turn- } \\
\text { over }\end{array}$ & $\begin{array}{c}\text { Serum } \\
\text { iron }\end{array}$ & $\begin{array}{c}\text { Total } \\
\text { iron- } \\
\text { binding } \\
\text { capac- } \\
\text { ity }\end{array}$ & $\begin{array}{c}\text { Plasma } \\
\text { radio- } \\
\text { iron } \\
\text { clear- } \\
\text { ance } \\
t_{\frac{1}{2}}\end{array}$ & $\begin{array}{l}\text { RBC } \\
\text { radio- } \\
\text { iron } \\
\text { uptake }\end{array}$ & $\begin{array}{l}\text { Red cell } \\
\text { life-span }\end{array}$ & $\begin{array}{c}\text { Fecal } \\
\text { urobi- } \\
\text { linogen }\end{array}$ & $\begin{array}{c}\text { Hemin- } \\
14 C \\
\text { day } \\
9-20\end{array}$ & $\begin{array}{l}\text { Urobilin- } \\
\text { 14C } \\
\text { maximal } \\
\text { value }\end{array}$ \\
\hline & & \multicolumn{2}{|c|}{$m g / k g / d a y$} & \multicolumn{2}{|c|}{$\mu \mathrm{g} / 100 \mathrm{ml}$} & $\min$ & $\%$ & days & $m g / d a y$ & \multicolumn{2}{|c|}{$d p m / m g$} \\
\hline R.P. & Normal & 0.53 & 0.43 & 90 & 290 & 68 & 83 & & & 110 & 142 \\
\hline W.G. & Normal & 0.40 & 0.37 & 62 & 284 & 52 & 91 & & & 153 & 223 \\
\hline S.S. & $\begin{array}{l}\text { September } 1961 \\
\text { November } 1961\end{array}$ & & 0 & 210 & 210 & 293 & $\mathbf{0}$ & & $\begin{array}{l}800 \dagger \\
800 \dagger\end{array}$ & 461 & $\begin{array}{r}48 \\
459\end{array}$ \\
\hline \multirow[t]{3}{*}{ A.H. } & January 1963 & 0.31 & 0.005 & 271 & 271 & 390 & 1.6 & $\begin{array}{r}19 \\
\left(\mathrm{Hb} \mathrm{t}_{\mathrm{t}_{2}}\right)\end{array}$ & $400 \dagger$ & 0 & 22 \\
\hline & March 1963 & 0.74 & 0.610 & 80 & 146 & 57 & 82 & $\begin{array}{c}44 \\
\left(\mathrm{DFP}-{ }^{2} \mathrm{H}\right)\end{array}$ & $400 \dagger$ & 404 & 1,291 \\
\hline & July 1964 & 0.63 & 0.384 & 213 & 213 & 131 & 61 & $\begin{array}{c}86 \\
(\text { Hemin-14C) }\end{array}$ & 293 & 196 & 596 \\
\hline J.F. & April 1962 & & & & & & & & $800 \dagger$ & 9 & 15 \\
\hline \multirow[t]{4}{*}{ L.F. } & November 1961 & 1.06 & 0.15 & 202 & 202 & 95 & 14 & $\begin{array}{c}72 \\
(\text { DFP-8H) }\end{array}$ & $400 \dagger$ & 30 & 1,650 \\
\hline & November 1962 & 0.72 & 0.43 & 60 & 140 & 93 & 60 & $\begin{array}{c}131 \\
\left(\mathrm{DFP}-{ }^{-3} \mathrm{H}\right)\end{array}$ & $220 \dagger$ & 70 & 125 \\
\hline & May 1963 & 0.45 & 0.18 & 181 & 181 & 154 & 40 & $\left({ }^{51} \mathrm{Cr}\right)^{33}$ & 81 & 110 & $343 \ddagger$ \\
\hline & January 1964 & 0.76 & 0.11 & 185 & 207 & 120 & 15 & $\left(\mathrm{Hb} \mathrm{t}_{\frac{1}{2}}\right)$ & 419 & 52 & 502 \\
\hline
\end{tabular}

*Abbreviations: $\mathrm{RBC}=$ red blood cell, $\mathrm{Hb}=$ hemoglobin, and DFP-2H $=$ tritiated diisopropylfiuorophosphate. 


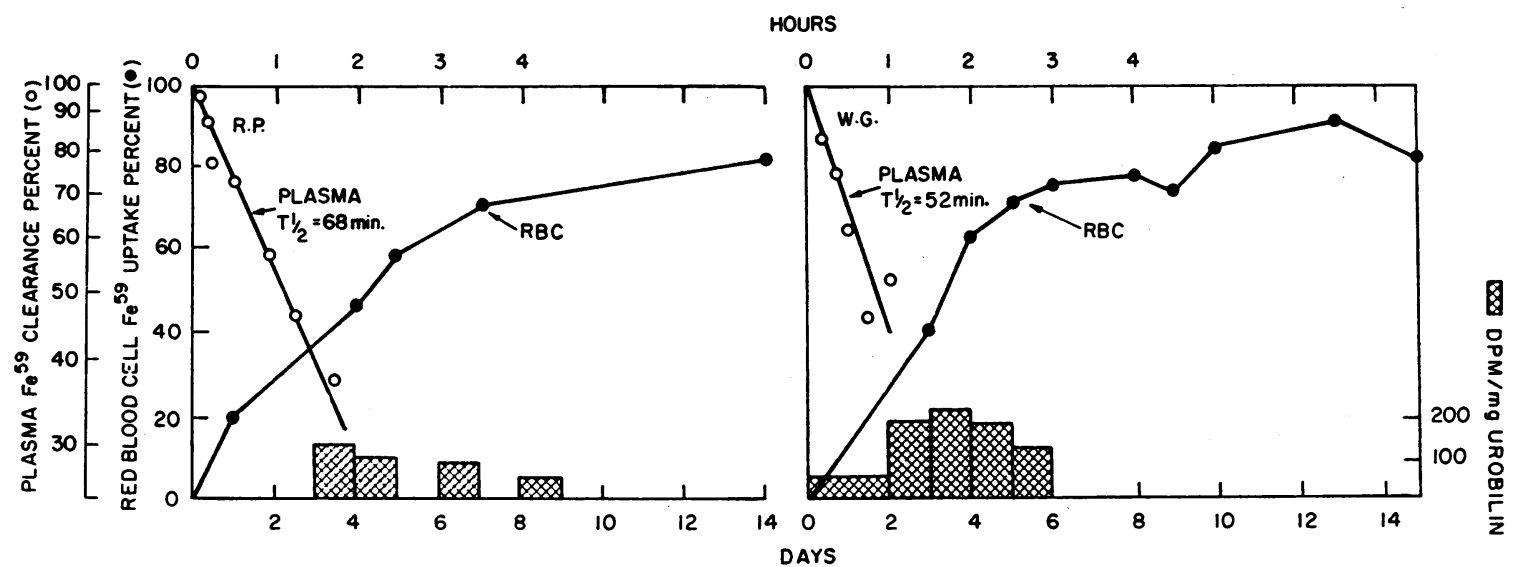

Fig. 1. ERythrokinetic studies of two hematologically noRmal patients, R.P. and W.G. The radioiron plasma disappearance and red cell (RBC) uptake, used here as an index of the rate of erythropoiesis, are shown as lines connecting the circles; the bar graphs of urobilin- ${ }^{\text {"C }} \mathrm{C}$ specific activity represent the "early peak."
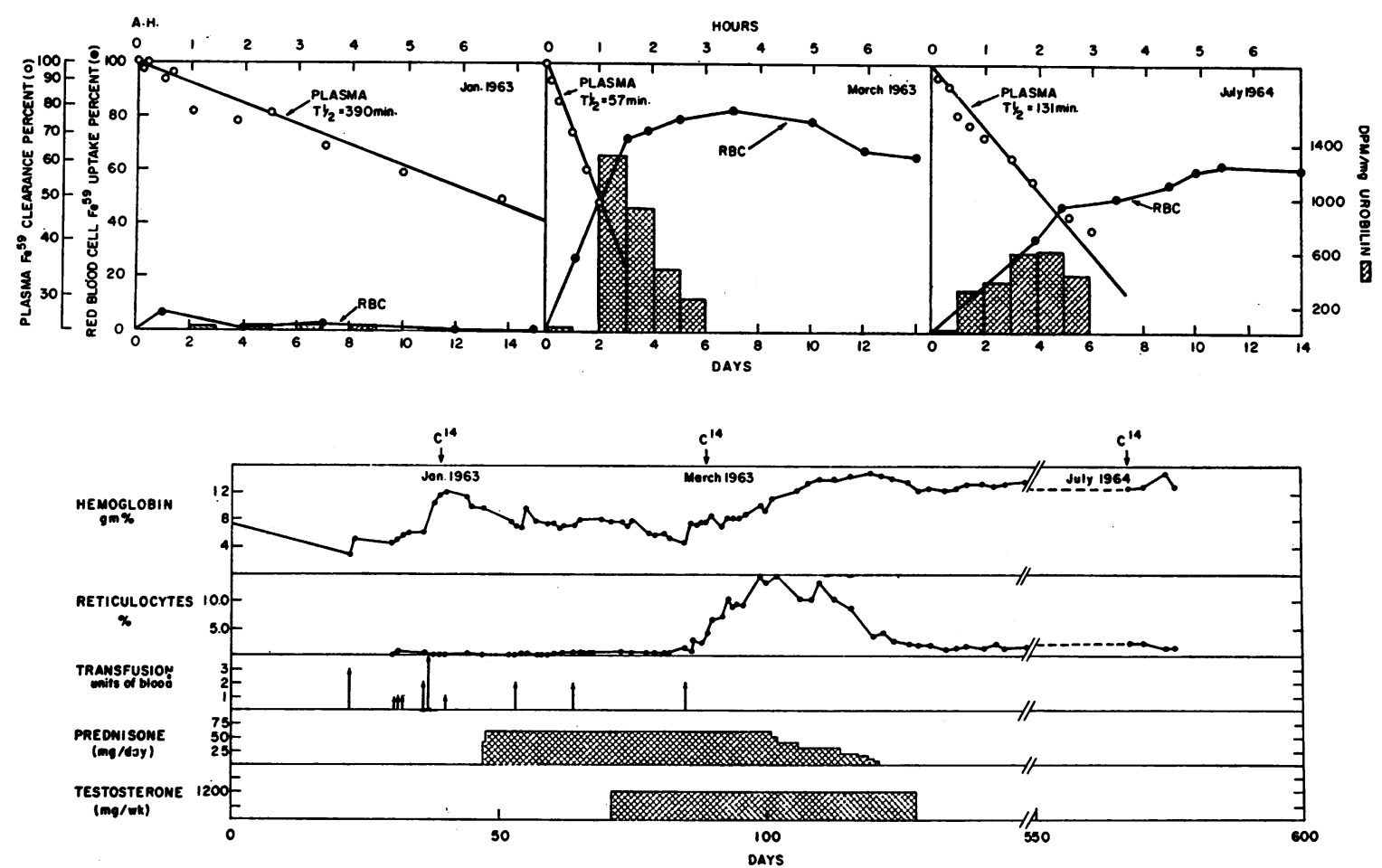

Fig. 2. ERYthrokinetic studies AND Clinical course of patient A.H. The three studies illustrated above, from left to right, indicate the radioiron and urobilin $-{ }^{14} \mathrm{C}$ data obtained before treatment of erythroid hypoplasia, after successful treatment, and 18 months later. The three small arrows at the top margin of the clinical data indicate the times when the glycine-2- ${ }^{14} \mathrm{C}$ and radioiron studies were performed. The specific activity of the early peak of urobilin ${ }^{14} \mathrm{C}$, represented by the bar graphs, varied with changes in the rates of plasma clearance and red cell incorporation of radioiron. 


\section{Results}

Clinical course and erythrokinetic data for each patient may be found in Figures 1-6. Case histories are in the Appendix. The data have also been tabulated in Table I.

Three of the four patients were studied during two or more phases of their illnesses. For comparison, two hematologically normal individuals, R.P. and W.G., were also studied (Figure 1). R.P. had a localized carcinoma of the tongue, and W.G. had psoriasis. Their respective ferrokinetic studies were as follows: plasma radioiron disappearance half-time, 68 and 52 minutes; and maximal red cell ${ }^{50} \mathrm{Fe}$ incorporation, 83 and $91 \%$. Plasma iron turnover (PIT) values were 0.53 and $0.40 \mathrm{mg}$ per $\mathrm{kg}$ per day, and red cell iron turnover (RCIT) was 0.43 and $0.37 \mathrm{mg}$ per $\mathrm{kg}$ per day. Two weeks after injection of $100 \mu \mathrm{c}$ of glycine-2-14 $\mathrm{C}$, the hemin- ${ }^{14} \mathrm{C}$ specific activities were, respectively, 110 and $153 \mathrm{dpm}$ per $\mathrm{mg}$, and in two other hematologically normal patients the values were 115 and $152 \mathrm{dpm}$ per mg. The peak specific activities of the urobilin- ${ }^{14} \mathrm{C}$ were 142 and $223 \mathrm{dpm}$ per mg. These maximal values for the urobilin- ${ }^{14} \mathrm{C}$ specific activity in hematologically normal individuals compare favorably with the maximal specific activity of $91 \mathrm{dpm}$ per $\mathrm{mg}$ obtained by White (18) in a normal adult after the intravenous injection of $100 \mu \mathrm{c}$ glycine-2-14 $\mathrm{C}$. Two additional hematologically normal subjects have been studied by Gray and Scott (7) and
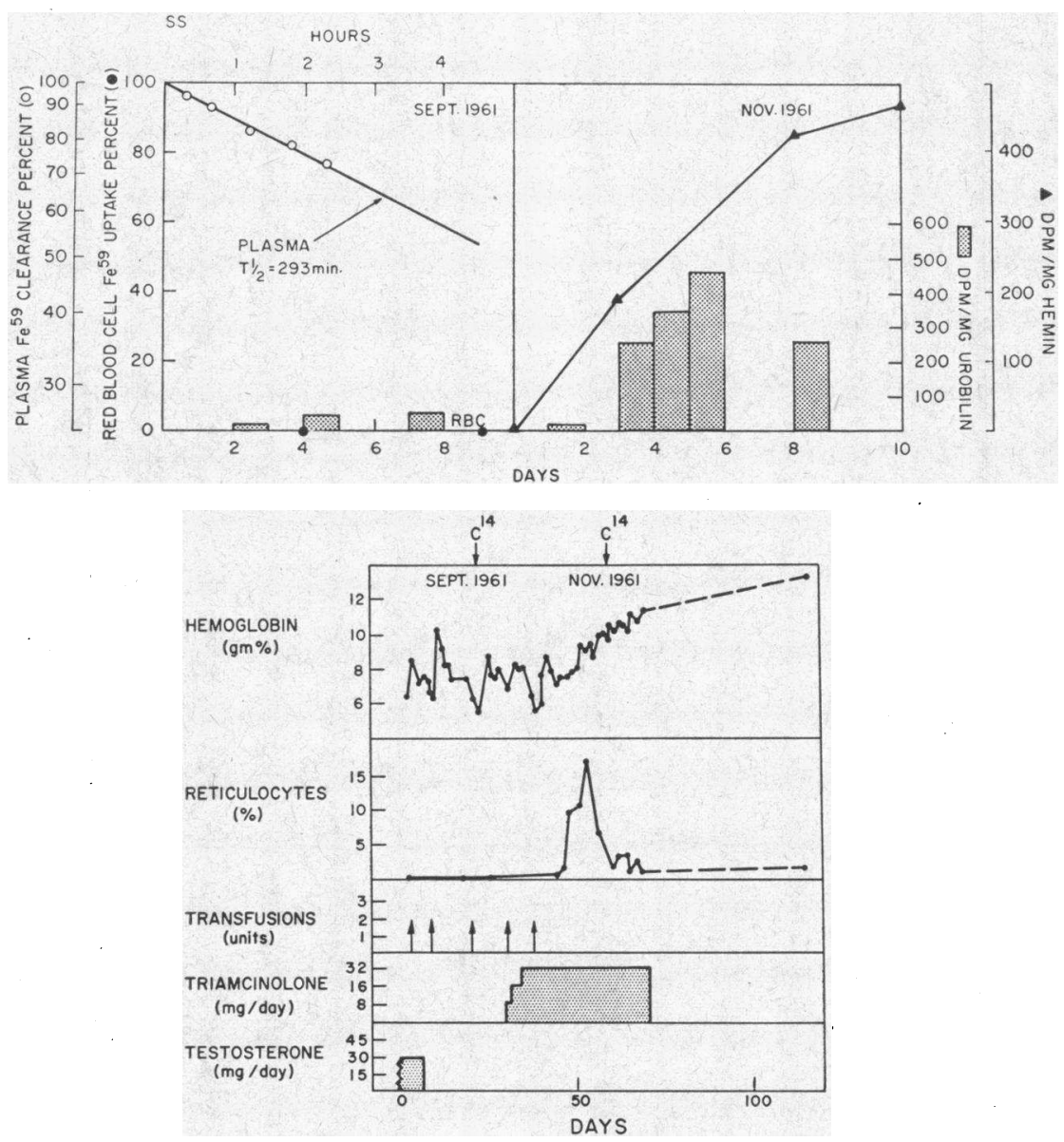

Fig. 3. ERythrokinetic studies and clinical course of patient S.S. At the time of the first study, when the patient had profound erythroid hypoplasia, there was very little incorporation of isotopic precursors into red cells or the early peak. However, after treatment, red cell production returned, and the amount of isotopic glycine incorporated into hemin and into the urobilin $-{ }^{14} \mathrm{C}$ early peak was greater than normal. 
Israels and Zipursky (19); one was given $25 \mu \mathrm{c}$ glycine $-2-{ }^{14} \mathrm{C}$ orally and the other, $50 \mu \mathrm{c}$ intravenously. The maximal observed fecal urobilin specific activities can be extrapolated to a dose of $100 \mu \mathrm{c}$, assuming factors of 4 and 2 , respectively, to yield calculated peak fecal urobilin specific activities of approximately 75 and $286 \mathrm{dpm}$ per $\mathrm{mg}$, respectively.

Patient A.H. (Figure 2), a 57-year-old man with chronic lymphocytic leukemia, was found to have almost complete erythroid aplasia of the bone marrow at the time of the initial study (January 1963). The plasma radioiron disappearance halftime was 390 minutes, and there was virtually no incorporation of radioiron into red cells and of glycine- ${ }^{14} \mathrm{C}$ into urobilin and hemin. The specific activity of the urobilin was $22 \mathrm{dpm}$ per $\mathrm{mg}$, and that of the hemin was $0 \mathrm{dpm}$ per mg. PIT was 0.31 and RCIT 0.005 , mg per $\mathrm{kg}$ per day. However, after treatment with prednisone and testosterone a reticulocytosis occurred, and a second study was performed (March 1963). Plasma radioiron disappearance half-time was 57 minutes, with a maximal radioiron red cell uptake of $82 \%$. PIT was 0.74 and RCIT $0.61, \mathrm{mg}$ per kg per day. The specific activity of hemin- ${ }^{14} \mathrm{C}$ after 2 weeks was $404 \mathrm{dpm}$ per $\mathrm{mg}$, and the maximal specific activity of urobilin $-{ }^{14} \mathrm{C}$ was $1,291 \mathrm{dpm}$ per $\mathrm{mg}$, which is greatly elevated. The patient was studied again in July 1964. Plasma radioiron disappearance halftime was 131 minutes, and maximal radioiron red cell uptake was $61 \%$. PIT was 0.63 and RCIT $0.38, \mathrm{mg}$ per $\mathrm{kg}$ per day. The specific activity of the hemin- ${ }^{14} \mathrm{C}$ was $196 \mathrm{dpm}$ per mg, and hemin${ }^{14} \mathrm{C}$ red cell life-span was 86 days. The specific activity of urobilin- ${ }^{14} \mathrm{C}$ reached a maximum of $596 \mathrm{dpm}$ per $\mathrm{mg}$.

Patient S.S. was a 45-year-old woman with chronic lymphocytic leukemia. In the first study (Figure 3) her bone marrow showed almost complete erythroid aplasia. Ferrokinetic studies showed a prolonged plasma radioiron disappearance half-time of 293 minutes, with no radioiron incorporation into circulating red cells. The maximal specific activity of urobilin- ${ }^{14} \mathrm{C}$ was $48 \mathrm{dpm}$ per $\mathrm{mg}$. The second study was done shortly after the peak of reticulocytosis, when the bone marrow contained $10 \%$ erythroid precursors, many of which showed megaloblastoid changes. A radioiron study was not performed, but the maximal

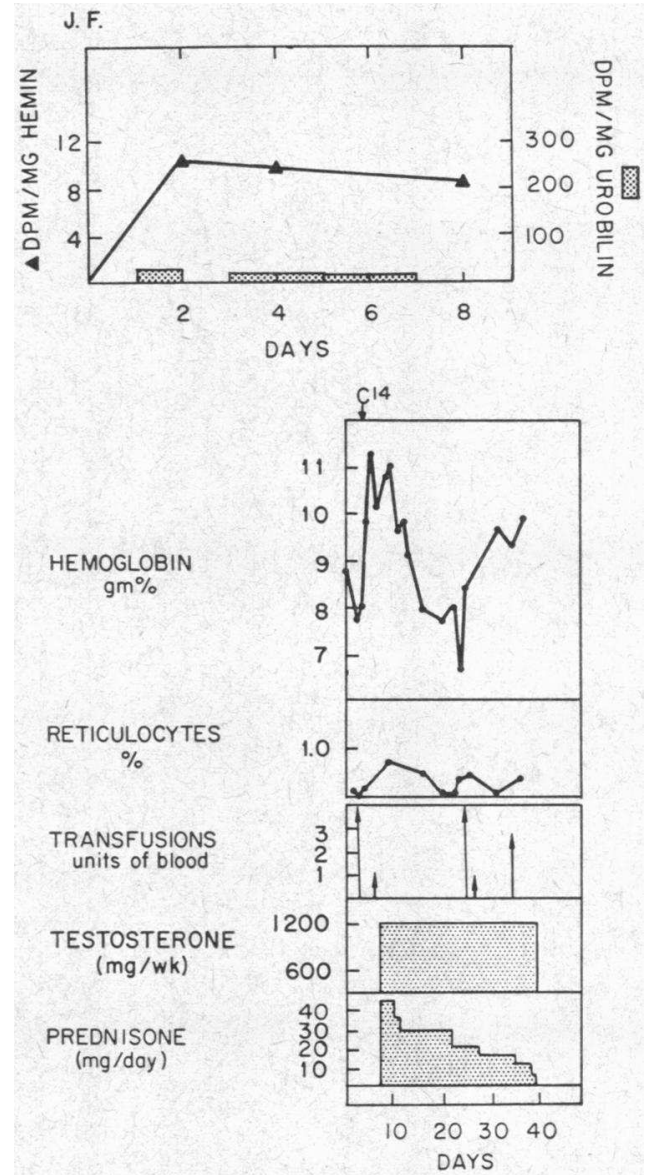

Fig. 4. ERythrokinetic studies and CLINical course of PATIENT J.F. This patient with aplastic anemia was studied on only one occasion. The maximal specific activities of the hemin- ${ }^{14} \mathrm{C}$ and urobilin- ${ }^{14} \mathrm{C}$ were both approximately $10 \%$ of the values found in normal individuals after a similar amount of glycine $-2-{ }^{14} \mathrm{C}$.

specific activity of hemin- ${ }^{14} \mathrm{C}$ was $461 \mathrm{dpm}$ per mg, which is greater than normal (20). The specific activity of the urobilin- ${ }^{14} \mathrm{C}$ early peak was also greater than normal, with a maximal value of 459 dpm per mg.

J.F., a patient with aplastic anemia (Figure 4), was found to have hypoplastic bone marrow. Glycine- ${ }^{14} \mathrm{C}$ incorporation into hemin decreased markedly (9 dpm per $\mathrm{mg}$ ). Maximal urobilin $-{ }^{14} \mathrm{C}$ specific activity was very low (15 dpm per $\mathrm{mg}$ ).

Patient L.F. had refractory anemia with erythroid hyperplasia of the bone marrow, but at autopsy a diagnosis of multiple myeloma was made. Over $2 \frac{1}{2}$ years, four studies were performed on this patient. In the first (Figure 5, November 

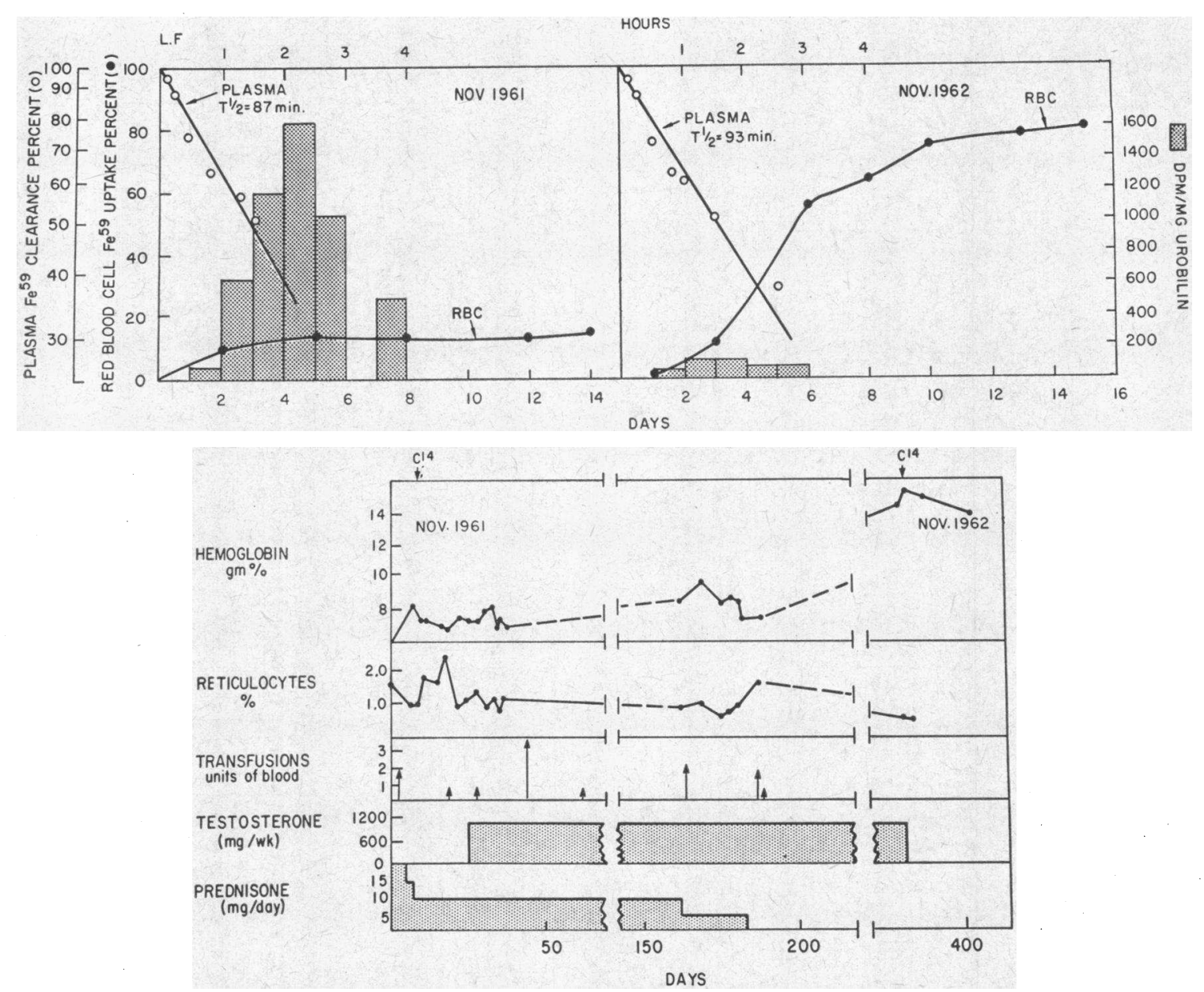

Fig. 5. ERYthrokinetic studies AND Clinical course of Patient L.F. Four studies were performed on L.F., a patient with refractory anemia. At the time of the first study, there was a large transfusion requirement and an extremely high specific activity of the urobilin $-{ }^{11} \mathrm{C}$ early peak. The second study, performed after treatment, showed that the red cell production had returned towards normal and the specific activity of the urobilin- ${ }^{14} \mathrm{C}$ early peak was within the normal range. The third and fourth studies are shown in Figure 6.

1961), plasma radioiron disappearance half-time was normal ( 87 minutes), but red cell radioiron uptake was low (14\%). PIT was 1.06 and RCIT $0.15, \mathrm{mg}$ per $\mathrm{kg}$ per day. The maximal specific activity of urobilin- ${ }^{14} \mathrm{C}$ was $1,650 \mathrm{dpm}$ per $\mathrm{mg}$, which is markedly elevated. A hemin $-{ }^{14} \mathrm{C}$ red cell life-span was 52 days, with a maximal specific activity of $30 \mathrm{dpm}$ per mg. In November 1962 (Figure 5), after treatment with testosterone, the patient's plasma radioiron uptake was $60 \%$. PIT at this time was 0.72 and RCIT 0.43 , mg per kg per day. Red cell life-span (DFP-s ${ }^{3}$ ) was 131 days. The specific activity of urobilin $-{ }^{14} \mathrm{C}$ was $125 \mathrm{dpm}$ per $\mathrm{mg}$, which is within the normal range, and the maximal specific activity of hemin ${ }^{14} \mathrm{C}$ was slightly low (70 dpm per mg) (20). In May 1963 (Figure 6), when the patient's rate of erythropoiesis had decreased, plasma radioiron disappearance half-time was 154 minutes, and red cell uptake was $40 \%$. PIT was 0.40 , and RCIT 0.18 , mg per $\mathrm{kg}$ per day. The ${ }^{51}$ chromium red cell survival half-time was 33 days. Maximal specific activity of urobilin- ${ }^{14} \mathrm{C}$ was $343 \mathrm{dpm}$ per $\mathrm{mg}$, and that of hemin- ${ }^{14} \mathrm{C}$ was $110 \mathrm{dpm}$ per $\mathrm{mg}$. In January 1964 (Figure 6), when the patient had a large transfusion requirement, plasma radioiron disappearance half-time was 120 minutes, with a red cell radioiron uptake of $15 \%$. PIT was 0.76 and 

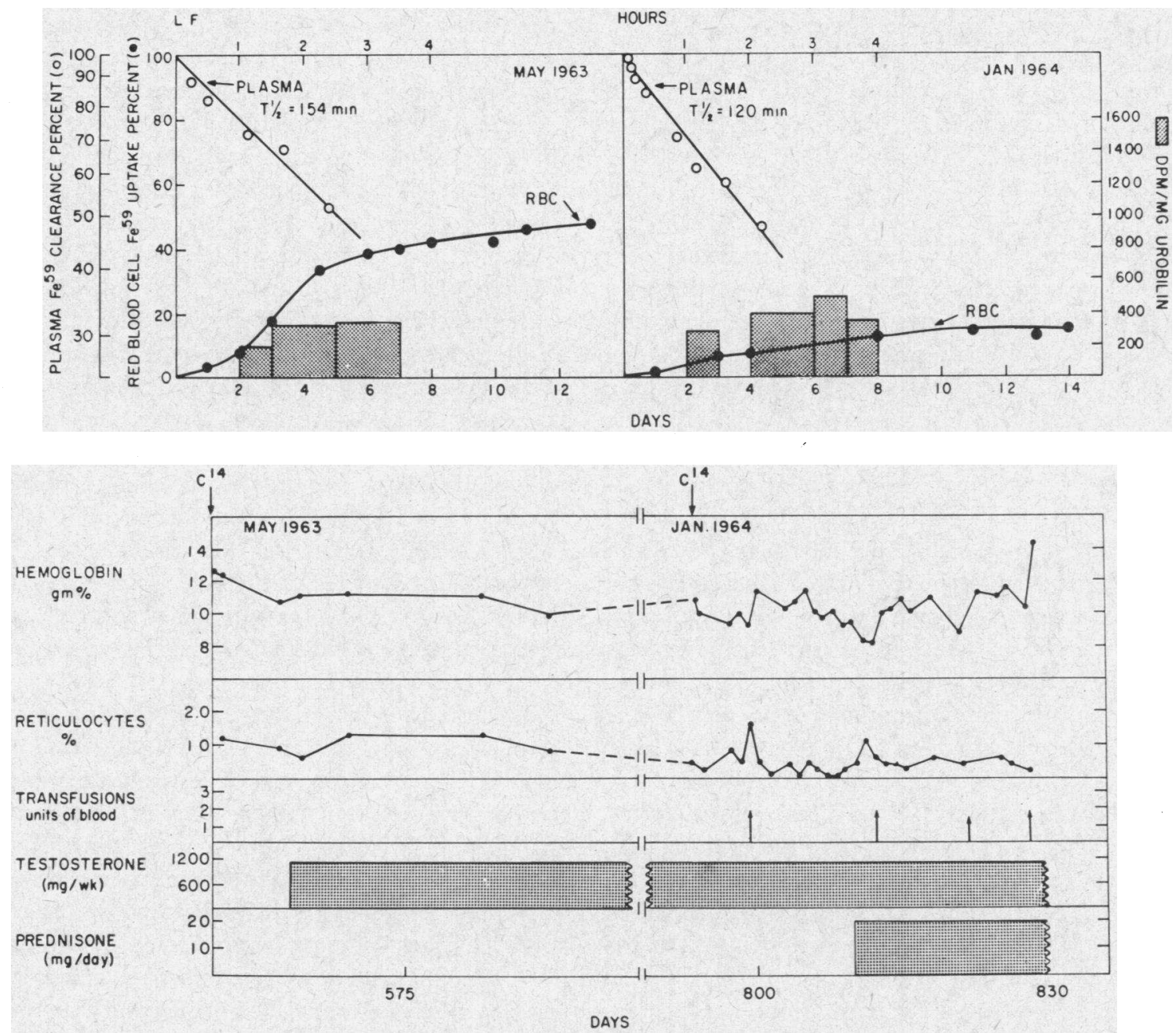

Fig. 6. Erythrokinetic studies and clinical course of patient L.F. The third and fourth studies in L.F., who had previously responded to treatment, were performed when red cell production decreased and the patient became refractory to treatment. Concomitantly, the specific activity of the urobilin- ${ }^{14} \mathrm{C}$ early peak increased to levels greater than normal.

RCIT 0.10 , mg per $\mathrm{kg}$ per day. Maximal specific activity of urobilin-14 $\mathrm{C}$ was $502 \mathrm{dpm}$ per $\mathrm{mg}$, and that of hemin- ${ }^{14} \mathrm{C}$ was $52 \mathrm{dpm}$ per $\mathrm{mg}$.

\section{Discussion}

The early labeled peak was first observed by Gray and co-workers (2) and London and coworkers (1) in 1950. Both groups felt that the early peak was probably related to erythropoiesis. Subsequent studies in disease states with increased erythropoiesis and after an experimental hemorrhage indicated that the maximal specific activity was increased when the rate of erythropoiesis was increased (6). However, James and Abbott (5) reported studies performed on a patient in which an increased early labeled peak was found at a time when the bone marrow showed erythroid aplasia.

The present study was designed to determine whether the early peak in man is in fact related to erythropoiesis by measuring the incorporation of glycine- $2-{ }^{14} \mathrm{C}$ into the urobilin $-{ }^{14} \mathrm{C}$ early peak at a time when erythropoiesis was markedly reduced or absent as judged by bone marrow examination, reticulocyte count, radioiron plasma clearance and red cell uptake, and glycine- $2-{ }^{14} \mathrm{C}$ incorporation into red cell heme. 
Before treatment three patients (A.H., S.S., and J.F.) were found to have a very small early labeled peak when erythropoiesis was markedly reduced and erythroid hypoplasia of the bone marrow was present. After treatment had restored erythropoiesis in two of these patients (A.H. and S.S.), the early labeled peak of urobilin was found to be increased above normal and markedly increased in comparison with the studies performed when erythropoiesis was absent. The third patient (J.F.) did not respond to therapy.

Patient L.F., in contrast to the preceding three patients, initially had erythroid hyperplasia of the bone marrow. In his first study (Figure 5, November 1961), the presence of anemia and the decreased incorporation of radioiron into circulating red cells, together with a normal plasma radioiron disappearance half-time, a markedly elevated early peak, and erythroid hyperplasia, suggest that a large amount of ineffective erythropoiesis was present. Maximal specific activity of the early peak was 1,650 dpm per $\mathrm{mg}$, which is much higher than the normal range of 75 to 286. A year later (November 1962), the second study was performed. The patient did not require transfusions, and the ferrokinetic studies were normal, suggesting that the synthesis of red cells had returned toward normal. The early peak had also fallen to normal levels. In the ensuing months the patient's effective red cell production slowly decreased, as evidenced by anemia and an increasing transfusion requirement. Concomitantly, the studies in May 1963 and January 1964 (Figure 6) showed an increasing urobilin- ${ }^{14} \mathrm{C}$ specific activity, suggesting that the bone marrow was synthesizing red cells in adequate numbers but that there were defective cells that were catabolized either in the marrow or shortly after their release into the peripheral blood. The hemoglobin${ }^{14} \mathrm{C}$ contained in the defective red cells was presumably converted to urobilin- ${ }^{14} \mathrm{C}$, and thus an increased isotope content of the early peak was observed. This combination of findings can be designated as ineffective erythropoiesis.

When patients A.H., S.S., and J.F. had erythroid hypoplasia of the bone marrow, essentially no erythropoiesis, and a low early peak, one may speculate that the metabolic defect was in the synthesis of hemoglobin. However, in patient L.F. with bone marrow erythroid hyperplasia, an ele- vated early peak, and a normal radioiron plasma clearance, it is likely that the defect occurred at a later stage and could involve the mechanism of nuclear extrusion. Electron microscopic studies by Bessis, Breton-Gorius, and Thiery (21) suggested that 5 to $10 \%$ of the reticulocyte cytoplasmic hemoglobin is lost at the time of nuclear extrusion, and Hammel and Bessman (22) have indicated that the nucleus itself may be the site of a significant amount of hemoglobin. It is possible that if the nuclear extrusion mechanism went awry, large amounts of labeled hemoglobin would be found. It is also possible that in the normal individual the hemoglobin contained in the perinuclear cytoplasm and in the nucleus itself could represent a major source of the early peak of labeled urobilin, a possibility that would be consistent with our studies in which changes in the amounts of labeled precursor in the early peak were associated with changes in the rate of effective erythropoiesis.

After the injection of glycine-2-14 $\mathrm{C}$, Yamamoto, Skanderbeg, Zipursky, and Israels (23) found two peaks of isotopic incorporation in plasma bilirubin, one occurring within the first day and the second during the fourth day. The occurrence of the second peak corresponds to the time of nuclear extrusion of the group of red cells that would contain the largest amount of an isotopic precursor (24). Evidence that labeled bilirubin appears in dog fistula bile before labeled heme can be detected in the bone marrow has also been presented (4), suggesting that a nonheme pathway for labeled bile pigment might exist. However, it is more likely that various heme-containing enzymes with rapid turnover times, such as those in the liver, may contribute to the early labeled peak, and it may be this source that accounts for the first of the two plasma bilirubin peaks. This concept is supported by recent studies in bile-fistula dogs $(25,26)$ in which the early peak of bile bilirubin was separated into erythropoietic and nonerythropoietic fractions by stimulating or suppressing erythropoiesis. It was found that in the normal state one-half to twothirds of the early peak was of erythropoietic origin, and that the remainder could be accounted for by the radioactivity present as hepatic nonhemoglobin heme. The presence of a hepatic contribution to the early peak of labeled urobilin in man is suggested by studies in which an early peak ap- 
peared in a normal individual after the ingestion of delta-aminolevulinic acid-14 $\mathrm{C}$, a poor in vivo precursor of red cell heme (27), and also by the initial studies in patients A.H. and S.S., in whom urobilin specific activity was found to be very low but never absent, whereas virtually no radioiron was incorporated into the red cells (Figures 2 and 3 ). In man, however, pigment production associated with erythropoiesis certainly constitutes the bulk of the fecal urobilin early peak, as shown by the extremely low urobilin specific activity in the absence of erythropoiesis in patients A.H., S.S., and J.F.

Theoretically, once the specific activity of the urobilin is known, it should be possible to calculate the total amount of precursor in the early peak if the total urobilin excretion is also known. However, the quantitative fecal urobilinogen determination is inexact, and meaningful calculations cannot be made $(6,8)$. Alternatively, the amount of labeled precursor in the early and late peaks could be compared, but this would require steady state conditions for more than 120 days and would be impossible in patients without a "late" peak, such as those with rapid rates of hemolysis or those in whom the amount of labeled precursor incorporated into circulating red cells is very small. These difficulties make it necessary for one to evaluate the early peak of labeled urobilin excretion in terms of the maximal specific activity. This is a valid concept if the precursor is given intravenously over a short period of time and if fecal samples are analyzed in 1-day blocks as was done in this study. This method of comparison requires that the area under the curve be proportional to the maximal value and that the urobilin production be constant, thus making the maximal value the principal variable reflecting the total amount of isotope in the peak. With these assumptions, the contribution to the early peak in man that is not due to erythropoiesis may be estimated as approximately 7 to $10 \%$ (J.F.), 10 to $15 \%$ (A.H.), and 22 to $34 \%$ (S.S.). ${ }^{3}$

The possibility that the differences observed in the urobilin specific activities before and after treatment could be the result of changes in the

3 These estimates represent a comparison of the maximal urobilin $-{ }^{14} \mathrm{C}$ specific activities in these patients when erythropoiesis was virtually absent to those observed in control patients R.P. and W.G. total daily excretion of bile pigment was also examined. Although fecal urobilinogen determinations were not obtained in every case, it was possible to estimate the rate of pigment excretion from the transfusion requirement and the rate of change of venous hemoglobin concentration. When we made these calculations, we found that the maximal change in total bile pigment excretion was twofold, whereas the smallest change in the preand post-therapy urobilin maximal specific activities was ninefold. Thus-despite some variation in the total pigment excretion-because of the large change in the specific activity before and after treatment, it is clear that the maximal urobilin specific activities are a presently acceptable reflection of the rate of isotope excretion.

\section{Summary}

An "early peak" of labeled fecal urobilin excretion occurs during the first few days after the intravenous administration of glycine- $2-{ }^{14} \mathrm{C}$ to man. To determine if this early peak is associated with erythropoiesis, we gave four patients with hematologic diseases and two hematologically normal patients glycine-2-14 $\mathrm{C}$, a precursor of bile pigment, and thereafter made determinations of the amount of radioactivity in the fecal urobilin. Three patients were studied when erythropoiesis was virtually absent, and in all three instances the specific activity of the fecal urobilin- ${ }^{14} \mathrm{C}$ was markedly reduced when compared to hematologically normal subjects. Two patients (S.S. and A.H.) were studied a second time during a period of reticulocytosis and rising hemoglobin concentration. The maximal specific activity in the urobilin $-{ }^{14} \mathrm{C}$ increased approximately tenfold in patient S.S. and 60 -fold in A.H. Thus, the maximal urobilin- ${ }^{14} \mathrm{C}$ specific activity was shown to be low initially when compared with normal and to increase markedly when erythropoiesis was active. This suggests that a small early labeled peak is present in man in the absence of erythropoiesis but that the bulk of the peak is associated with red cell formation in the marrow in these patients. A fourth patient with anemia and normoblastic hyperplasia of the marrow was studied four times. In this patient the maximal urobilin $-{ }^{14} \mathrm{C}$ specific activity was shown to decrease by approximately 13 -fold concomitant with return of the bone marrow toward normal and return of effective erythropoiesis. 


\section{Acknowledgments}

We thank Drs. Cecil J. Watson and Samuel Schwartz and their laboratory staff, Irene Bossenmaier, Ruth Cardinal, and Mary Weimer, for generous advice and encouragement. In addition, we thank Dr. John J. Scott for help in the initial phases of the study and Jeanne Waggoner and Donald Van Houten for technical assistance.

\section{Appendix}

\section{Case histories of patients}

A.H. (NIH no. 02-63-51), a 57-year-old white man, was found in 1959 to have a leukocyte count of 290,000 per $\mathrm{mm}^{8}$, with $90 \%$ lymphocytes, and a bone marrow characteristic of chronic lymphocytic leukemia. He was treated in 1960 and 1961 with a total of 160 röentgens of whole body X-irradiation. In July 1962, the hemoglobin $(\mathrm{Hb})$ was $12.0 \mathrm{~g}$ per $100 \mathrm{ml}$, but by November it had dropped to 5.0, and in January 1963, at the time of initial study, it was found to be $2.9 \mathrm{~g}$ per $100 \mathrm{ml}$. His bone marrow showed $90 \%$ lymphocytes and no erythroid cells. He was treated with prednisone, but because there was no apparent response after 3 weeks, intramuscular injections of testosterone 4 were begun. After 2 weeks of this treatment, an increase in reticulocyte count was noted, and a second study was performed. The bone marrow was hypercellular with $35 \%$ lymphocytes and 45\% erythroid precursors. One and one-half years later, at the time of the third study, the $\mathrm{Hb}$ was $12.6 \mathrm{~g}$ per $100 \mathrm{ml}$, reticulocyte count was $1.5 \%$, and bone marrow aspiration revealed a hyperplastic marrow packed with lymphocytes and containing abundant reticulin and collagen fibrosis. Occasional normoblasts were seen.

S.S. (NIH no. 01-49-65), a 41-year-old white woman, first sought medical attention in 1956 because of fatigue. She was found to have cervical adenopathy, splenomegaly, and profound anemia. The leukocyte count was 1,000 per $\mathrm{mm}^{2}$, with $80 \%$ lymphocytes, and the reticulocyte count was $0 \%$. Her bone marrow showed normal cellularity with infiltration by small lymphocytes; a diagnosis of chronic lymphocytic leukemia was made. Chemotherapy was given, and subsequently the cellular elements of the blood increased and transfusions were no longer necessary. In late 1959 pancytopenia again developed but was successfully treated by splenectomy. In mid-1960, however, transfusions again became necessary. The bone marrow showed a striking decrease in the number of erythroid precursors, with a myeloid: erythroid ratio of 20:1. During the summer of 1961, the patient was treated with a testosterone preparation 5 with no apparent effect. The first of the patient's two studies was done at this time. In October the patient began on triamcinolone, ${ }^{6}$ and 1 week later reticulocytosis began. The

4 Depo-testosterone cyclopentylpropionate, Upjohn Co., Kalamazoo, Mich.

Halotestin, Upjohn Co.

6 Aristocort, Lederle Laboratories, Pearl River, N. Y. second study was done during reticulocytosis. The patient developed chronic otitis media and died with a septicemia in February 1962.

J.F. (NIH no. 04-19-59), a 17-year-old Negro male student, was admitted in April 1962 with a diagnosis of idiopathic aplastic anemia. No abdominal organs were palpable, and an axillary lymph node biopsy was normal. The Hb was $8.7 \mathrm{~g}$ per $100 \mathrm{ml}$, the platelet count was 5,000 per $\mathrm{mm}^{3}$, and the leukocyte count was 800 per $\mathrm{mm}^{3}$, with $90 \%$ lymphocytes and $8 \%$ polymorphonuclear leukocytes (PMN). The reticulocyte count was 0 , and the bone marrow was markedly hypocellular, with $20 \%$ normoblasts and $66 \%$ lymphocytes. Prednisone and testosterone 4 were given without apparent response. The patient died several weeks after discharge.

L.F. (NIH no. 03-92-55), a 65-year-old white engineer, was first admitted in November 1961, with refractory anemia. There was no adenopathy or organomegaly. The transfusion requirement was $2 \mathrm{U}$ per month, the reticulocyte count was $1 \%$, the platelet count was 82,000 per $\mathrm{mm}^{3}$, and the leukocyte count was 3,000 per $\mathrm{mm}^{3}$, with $30 \%$ PMN and $70 \%$ lymphocytes. There were 75 nucleated red cells per 100 leukocytes. Moderate anisocytosis and poikilocytosis of the red cells were present, and the mean cell volume was $108 \mu^{3}$. The bone marrow was moderately hypercellular, with occasional megaloblastoid cells. Seventy-three per cent of the marrow cells were in the erythroid series, with abundant sideroblasts. No periodic acid-Schiff positive cytoplasmic inclusions were seen in the erythroid cells. Injections of a long acting testosterone preparation were begun, and prednisone was given until May 1962.

The patient was readmitted in November 1962. No transfusions had been necessary during the preceding 5 months. The $\mathrm{Hb}$ was $15.2 \mathrm{~g}$ per $100 \mathrm{ml}$, the reticulocyte count was $0.5 \%$, and the leukocyte count was 3,800 per $\mathrm{mm}^{3}$, with $60 \%$ PMN and $28 \%$ lymphocytes. The mean cell volume was $110 \mu^{3}$. The bone marrow hypercellularity was less marked, few sideroblasts were seen, and the maturation of the granulocytic and erythrocytic series was normal. The testosterone therapy was stopped.

The patient was admitted again in May 1963. In the interim the $\mathrm{Hb}$ had fallen slowly to $12 \mathrm{~g}$ per $100 \mathrm{ml}$. The fecal urobilinogen was $81 \mathrm{mg}$ per day, and serum protein electrophoresis revealed a total protein of 6.3 , albumin of 3.6, and gamma globulin of $1.2 \mathrm{~g}$ per $100 \mathrm{ml}$. The bone marrow contained many sideroblasts, and there was a mild shift to the left with $27 \%$ myeloblasts. Testosterone injections were reinstituted.

Transfusions became necessary in October 1963, at the rate of 3 to $4 \mathrm{U}$ per month. The patient was readmitted in January 1964. The fecal urobilinogen was $419 \mathrm{mg}$ per day. Bone marrow was hypercellular, with $40 \%$ of the cells present as abnormal erythroid elements with megaloblastoid changes. Many sideroblasts were present. The total protein was $6.6 \mathrm{~g}$ per $100 \mathrm{ml}$, and the albumin was $3.5 \mathrm{~g}$ per $100 \mathrm{ml}$. Unsuccessful trials of a number of hematinic agents were given, and the patient was then begun on prednisone in addition to testosterone. After 4 months no improvement was noted on this regimen. Be- 
cause of dysuria the patient was admitted to another hospital, where serum protein electrophoresis revealed a total protein of $7.8 \mathrm{~g}$ per $100 \mathrm{ml}$, with $32 \%$ albumin and $39 \%$ gamma globulin (broad band). The patient died suddenly after a prostatic biopsy. Autopsy examination revealed a hyperplastic marrow with many plasma cells, and a diagnosis of multiple myeloma was made.

\section{References}

1. London, I. M., R. West, D. Shemin, and D. Rittenberg. On the origin of bile pigment in normal man. J. biol. Chem. 1950, 184, 351.

2. Gray, C. H., A. Neuberger, and P. H. A. Sneath. Studies in congenital porphyria. 2. Incorporation of ${ }^{15} \mathrm{~N}$ in the stercobilin in the normal and in the porphyric. Biochem. J. 1950, 47, 87.

3. Israels, L. G., T. Yamamoto, J. Skanderbeg, and A. Zipursky. Shunt bilirubin: evidence for two components. Science 1963, 139, 1054.

4. Israels, L. G., J. Skanderbeg, H. Guyda, W. Zingg, and A. Zipursky. A study of the early-labelled fraction of bile pigment: the effect of altering erythropoiesis on the incorporation of $\left(2-{ }^{14} \mathrm{C}\right)$ glycine into haem and bilirubin. Brit. J. Haemat. 1963, 9, 50.

5. James, G. W. III, and L. D. Abbott, Jr. Stercobilin $\mathrm{N}^{15}$ excretion in refractory anemia. Trans. Amer. clin. climat. Ass. 1961, 73, 110.

6. Watson, C. J. Proceedings of the 9th Congress of the European Society of Haematology, Lisbon, 1963. Basel, S. Karger, pp. 817-832.

7. Gray, C. H., and J. J. Scott. The effect of haemorrhage on the incorporation of $\left(\alpha^{-1} \mathrm{C}\right)$ glycine into stercobilin. Biochem. J. 1959, 71, 38.

8. James, G. W. III. Stercobilin and hematopoiesis. Amer. J. clin. Nutr. 1955, 3, 64.

9. Watson, C. J. An improved method for the isolation of crystalline stercobilin. J. biol. Chem. 1934, $105,469$.

10. Watson, C. J., P. T. Lowry, V. E. Sborov, W. H. Hollinshead, S. Kohan, and H. O. Matte. A simple method of isolation of crystalline stercobilin or urobilin from feces. J. biol. Chem. 1953, 200, 697.

11. Gray, C. H., and D. C. Nicholson. The chemistry of the bile pigments. The structures of stercobilin and $d$-urobilin. J. chem. Soc. 1958, 627, 3085.

12. Fischer, H. Hemin in Organic Synthesis, N. L. Drake, Ed. New York, John Wiley, 1941, p. 53.
13. Berlin, N. I., C. Hewitt, and C. Lotz. Hippuric acid synthesis in man after the administration of $\left[\alpha-{ }^{14} \mathrm{C}\right]$ glycine. Biochem. J. 1954, 58, 498.

14. Huff, R. L., T. G. Hennessy, R. E. Austin, J. F. Garcia, B. M. Roberts, and J. H. Lawrence. Plasma and red cell iron turnover in normal subjects and in patients having various hematopoietic disorders. J. clin. Invest. 1950, 29, 1041.

15. Sterling, K., and S. J. Gray. Determination of the circulating red cell volume in man by radioactive chromium. J. clin. Invest. 1950, 29, 1614.

16. Read, R. C. Studies of red-cell volume and turnover using radiochromium. Description of a new "closed" method of red-cell-volume measurement. New Engl. J. Med. 1954, 250, 1021.

17. Cline, M. J., and N. I. Berlin. Measurement of red cell survival with tritiated diisopropylfluorophosphate. J. Lab. clin. Med. 1962, 60, 826.

18. White, $P$. Personal communication.

19. Israels, L. G., and A. Zipursky. Primary shunt hyperbilirubinaemia. Nature (Lond.) 1962, 193, 73.

20. Barrett, P. V. D., and N. I. Berlin. Unpublished observations.

21. Bessis, M., J. Breton-Gorius, and J.-P. Thiery. Rôle possible de l'hémoglobine accompagnant le noyau des érythroblastes dans l'origine de la stercobiline éliminée precocement. C. R. Acad. Sci. (Paris) 1961, 252, 2300.

22. Hammel, C. L., and S. P. Bessman. Hemoglobin synthesis in avian erythrocytes. J. biol. Chem. 1964, 239, 2228.

23. Yamamoto, T., J. Skanderbeg, A. Zipursky, and L. G. Israels. The early appearing bilirubin: evidence for two components. J. clin. Invest. 1965, 44, 31.

24. Nathan, D. G., S. Piomelli, and F. H. Gardner. The synthesis of heme and globin in the maturing human erythroid cell. J. clin. Invest. 1961, 40, 940.

25. Barrett, P. V. D., and N. I. Berlin. The relationship of the early-labelled bilirubin to erythropoiesis in the dog. Submitted for publication.

26. Schwartz, S., G. Ibrahim, and C. J. Watson. The contribution of nonhemoglobin hemes to the early labeling of bile bilirubin (abstract). J. Lab. clin. Med. 1964, 64, 1003.

27. Berlin, N. I., A. Neuberger, and J. J. Scott. The metabolism of $\delta$-aminolaevulic acid. 2. Normal pathways, studied with the aid of ${ }^{14} \mathrm{C}$. Biochem. J. 1956. 64, 90. 